\title{
DNA methylation: potential biomarker in Hepatocellular Carcinoma
}

Way-Champ Mah ${ }^{1,2,3}$ and Caroline GL Lee $1,2,3,4^{*}$

\begin{abstract}
Hepatocellular Carcinoma (HCC) is one of the most common cancers in the world and it is often associated with poor prognosis. Liver transplantation and resection are two currently available curative therapies. However, most patients cannot be treated with such therapies due to late diagnosis. This underscores the urgent need to identify potential markers that ensure early diagnosis of HCC. As more evidences are suggesting that epigenetic changes contribute hepatocarcinogenesis, DNA methylation was poised as one promising biomarker. Indeed, genome wide profiling reveals that aberrant methylation is frequent event in HCC. Many studies showed that differentially methylated genes and CpG island methylator phenotype (CIMP) status in HCC were associated with clinicopathological data. Some commonly studied hypermethylated genes include p16, SOCS1, GSTP1 and CDH1. In addition, studies have also revealed that methylation markers could be detected in patient blood samples and associated with poor prognosis of the disease. Undeniably, increasing number of methylation markers are being discovered through high throughput genome wide data in recent years. Proper and systematic validation of these candidate markers in prospective cohort is required so that their actual prognostication and surveillance value could be accurately determined. It is hope that in near future, methylation marker could be translate into clinical use, where patients at risk could be diagnosed early and that the progression of disease could be more correctly assessed.
\end{abstract}

Keywords: Epigenetics, Methylation, Biomarker, CIMP, Hepatocellular carcinoma, Prognosis, Diagnosis

\section{Introduction}

Hepatocellular Carcinoma (HCC) is one of the most frequent cancers in the world and annually, about 600,000 patients died of liver cancer [1]. This disease is often associated with poor prognosis because patients are either diagnosed at very late stage or experienced recurrence after resection [2]. In fact, more than half of HCC patients died within 12 months post diagnosis, and less than $6 \%$ of them have an average survival rate of 5 years [3]. Liver transplantation and resection are the only two curative therapies available; however, in order to qualify for such therapies, patients need to be diagnosed early with HCC [4]. Presently, serum alpha-fetoprotein (AFP) concentration and hepatic ultrasonography are used in

\footnotetext{
* Correspondence: caroline_lee@nuhs.edu.sg

'Department of Biochemistry, Yong Loo Lin School of Medicine, National University of Singapore, Singapore 117597, Singapore

${ }^{2}$ Division of Medical Sciences, Humphrey Oei Institute of Cancer Research,

National Cancer Centre Singapore, Level 6, Lab 5, 11 Hospital Drive,

Singapore 169610, Singapore

Full list of author information is available at the end of the article
}

HCC surveillance program, where high risk patients are screened for HCC in every six months [5]. As for actual diagnosis, invasive biopsy and expensive imaging tools such as ultrasonography, spiral computed tomography (CT) and magnetic resonance imaging (MRI) are used [4]. AFP measurement is merely used as adjunct diagnostic tool because of its variability in specificity and sensitivity $[5,6]$. Equally important to note is that apart from AFP level and tumor staging classification such as the Barcelona Clinic Liver Cancer (BCLC) staging system, there is no good prognostic marker that can classify patients and predict survival outcome [7-9]. The large number of HCC associated deaths clearly reflects the shortcomings of current diagnostic and prognostic tools. This underscores the importance of discovering novel and effective biomarkers that can improve overall clinical management of HCC.

With the advance of genomic technologies, plethora of molecular data is now available for translational research. Gene expression signatures and microRNA profiles are 
just some examples of molecular data that were actively explored as potential biomarkers for HCC [10-15]. In this review, we will focus specifically on DNA methylation, another potential biomarker that was shown to be implicated in $\mathrm{HCC}$.

\section{Review}

\section{Aberrant DNA methylation in HCC}

Studies have identified a few somatic mutations in HCC, for instance, mutations in TP53 [16,17], CTNNB1 [18,19], and AXIN1 [20,21]. However, frequencies of these mutations are inconsistent and rare, some occur only in certain subtypes of tumor [22]. The lack of common genetic marker associated with HCC cases strongly suggests that epigenetic alterations such as aberrant DNA methylation could be the alternative factor contributing towards liver carcinogenesis. DNA methylation occurs when a methyl group is attached to the $5^{\text {th }}$ carbon of cytosine nucleotide and this process is catalyzed by DNA methyltransferases (DNMTs), in which S-adenosyl-methionine (SAM) acts as a methyl donor (Figure 1) [23]. Deregulation of DNA methylation was shown to be associated with many cancers, as was first proposed by Andrew Feinberg and Bert Vogelstein in 1983 [24]. The two most common forms of aberrant methylation are global hypomethylation and sitespecific hypermethylation. In HCC, such deregulations are frequently observed as well. Global hypomethylation in liver cancer affects the structural-nuclear function by promoting chromosomal and genomic instability, while regional hypermethylation is often associated with silencing of tumor suppressor genes [25]. Studies have revealed that etiological factors like Hepatitis virus infection may lead to aberrant DNA methylation in cancerous tissues [26,27]. DNA methyltransferases such as DNMT1, DNMT3A and DNMT3B were also shown to be up-regulated in liver cancer $[28,29]$. Whether increased expression of DNMTs associated with aberrant methylation of genes is still a matter of controversy as the exact mechanism has yet to be elucidated $[29,30]$. Subsequent sections will summarize respective studies on aberrant DNA methylation in hepatocarcinogenesis and the full list of studies can be found in Additional file 1: Table S1.

\section{Genome wide studies on methylation profile of HCC}

Present technologies allow researchers to profile methylation in a genome wide manner. Two commonly used methods in HCC methylation profiling include hybridization of bisulfite converted DNA on beadarray [31,32] and enrichment of methylated DNA either by enzymatic digestion [33,34] or antibody pull-down [35], followed by promoter array profiling. Even though high throughput sequencing is becoming more available, presently, no study has yet to use this approach to map the methylome of HCC. Table 1 briefly summarizes the strengths and limitations of each profiling method. A few pivotal genome wide methylation studies using these approaches are highlighted below.

In 2008, Gao et al. adopted methylated CpG island amplification microarray (MCAM) method to identify 719 genes that were differentially methylated between tumors and adjacent non-tumors [36]. They used pyrosequencing to validate their observations found by MCAM. Genes such as RASSF1A, CDKN2A and CCNA1 were successfully validated to be highly methylated in cancer tissue compared to adjacent non-tumor and normal liver tissues. In subsequent year, Lu et al. used differential methylation hybridization (DMH) method to locate 38 hypomethylated and 27 hypermethylated regions. Using Methylation specific PCR (MSP) method, they validated the methylation status of KLK10 and OXGR1 in tumors, and found that hypermethylation of KLK10 was associated with Hepatitis $\mathrm{C}$ virus $(\mathrm{HCV})$ infection and cirrhosis [37]. Around the same time, studies by Deng et al. and Stefanska et al. used a slightly different method called methylated DNA immunoprecipitation microarray (MeDIP-chip) to locate aberrant methylation in HCC. Deng et al. used MassArray ${ }^{\circ}$ method to validate hypermethylation of DUSP4, NPR1 and CYP24A1 in HCC, and correlate methylation status

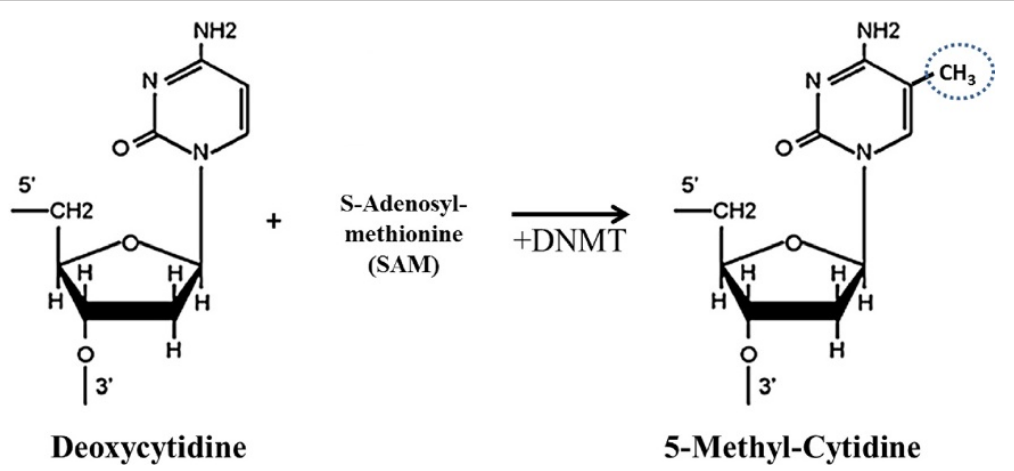

Figure 1 Structures of deoxycytidine and 5-methyl-deoxycytidine. DNA methylation occurs when a methyl group is attached to the $5^{\text {th }}$ carbon of cytosine, where DNMT serves as enzyme and SAM acts as the methyl group donor. 
Table 1 Different methods in genome-wide methylation profiling

\begin{tabular}{|c|c|c|c|c|c|c|c|}
\hline & Platform & Features & $\begin{array}{l}\text { Number of } \\
\text { regions } \\
\text { analysed } \\
\text { per sample }\end{array}$ & $\begin{array}{l}\text { Methylation } \\
\text { information } \\
\text { on site } \\
\text { specific CpG } \\
\text { loci }\end{array}$ & $\begin{array}{l}\text { Methylation } \\
\text { information } \\
\text { on non-CpG } \\
\text { loci }\end{array}$ & Advantages & Disadvantages \\
\hline \multirow[t]{3}{*}{$\begin{array}{l}\text { Microarray } \\
\text { based }\end{array}$} & $\begin{array}{l}\text { Methylated CpG } \\
\text { Island Amplification } \\
\text { and Microarray } \\
\text { (MCAM-chip) }\end{array}$ & $\begin{array}{l}\text { Enzyme-based techniques } \\
\text { that rely on restriction } \\
\text { enzymes (Smal and Xmal) } \\
\text { followed by profiling on } \\
\text { promoter array }\end{array}$ & \multirow[t]{3}{*}{$\begin{array}{l}\sim 25,000 \text { human } \\
\text { promoters (depends on } \\
\text { array density) }\end{array}$} & \multirow[t]{3}{*}{ No } & \multirow[t]{3}{*}{ No } & \multirow[t]{3}{*}{$\begin{array}{l}\text { Do not require bisulfite } \\
\text { conversion, good coverage on } \\
\text { region with low } \mathrm{CpG} \text { density. }\end{array}$} & \multirow{3}{*}{$\begin{array}{l}\text { Require substantial quantities of } \\
\text { input genomic DNA, low sample } \\
\text { throughput, do not report } \\
\text { methylation status at single } \\
\text { nucleotide level, bias may } \\
\text { occur due to genomic distribution } \\
\text { of CpG loci, limited to mostly } \\
\text { promoter regions. }\end{array}$} \\
\hline & $\begin{array}{l}\text { Differential Methylation } \\
\text { Hybridization and } \\
\text { Microarray (DMH-chip) }\end{array}$ & $\begin{array}{l}\text { Enzyme-based techniques } \\
\text { that rely on restriction } \\
\text { enzymes (Msel and BstUI) } \\
\text { followed by profiling on } \\
\text { promoter array }\end{array}$ & & & & & \\
\hline & $\begin{array}{l}\text { Methylated DNA } \\
\text { Immunoprecipitation } \\
\text { and Microarray } \\
\text { (MeDIP-chip) }\end{array}$ & $\begin{array}{l}\text { Immunoprecipitation of } \\
\text { methylated DNA with a } \\
\text { monoclonal antibody } \\
\text { followed by profiling on } \\
\text { promoter array }\end{array}$ & & & & & \\
\hline \multirow{3}{*}{$\begin{array}{l}\text { Beadarray } \\
\text { based }\end{array}$} & GoldenGate & \multirow{3}{*}{$\begin{array}{l}\text { Bisulfite convertion of DNA } \\
\text { followed by microbead } \\
\text { based microarray }\end{array}$} & $\sim 1,500$ CpG sites & \multirow[t]{3}{*}{ Yes } & \multirow[t]{3}{*}{ No } & \multirow{3}{*}{$\begin{array}{l}\text { Require minimum input } \\
\text { genomic DNA, high } \\
\text { sample throughput, } \\
\text { provide methylation } \\
\text { status at CpG loci, } \\
\text { fairly accurate and } \\
\text { reproducible. }\end{array}$} & \multirow{3}{*}{$\begin{array}{l}\text { Bisulfite treatment may not be } \\
\text { complete, bisulfite treatment } \\
\text { caused DNA degradation, limited } \\
\text { to mostly promoter regions. }\end{array}$} \\
\hline & Infinium 27K & & 27,000 CpG sites & & & & \\
\hline & Infinium 450K & & 450,000 CpG sites & & & & \\
\hline $\begin{array}{l}\text { High } \\
\text { throughput } \\
\text { sequencing }\end{array}$ & Bisulfite sequencing & $\begin{array}{l}\text { Bisulphite conversion of } \\
\text { DNA followed by capture } \\
\text { and high throughput } \\
\text { sequencing }\end{array}$ & Whole genome & Yes & Yes & $\begin{array}{l}\text { High resolution mapping of } \\
\text { methylation status at single } \\
\text { nucleotide level, no cross } \\
\text { hybridization bias. }\end{array}$ & $\begin{array}{l}\text { Bisulfite treatment may not be } \\
\text { complete, bisulfite treatment } \\
\text { caused DNA degradation, low } \\
\text { sample throughput, expensive, } \\
\text { complex bioinformatic analysis. }\end{array}$ \\
\hline
\end{tabular}


of these genes with recurrence free survival [38]. Stefanska et al., on the other hand, delineated the profile of promoter hypomethylation in HCC and validated AKR1B10, CENPH, MMP9, MMP12, PAGE4, S100A5, MMP2 and NUPR1 to be hypomethylated in liver cancer using pyrosequencing [39]. Earlier genome wide studies utilised promoter microarray to map out differentially methylated regions. As a result, such arrays could not provide information on site specific $\mathrm{CpG}$ dinucleotides that were aberrantly methylated. Additional validation steps such as pyrosequencing and MassArray ${ }^{\bullet}$ were required before one could locate the exact deregulated CpG sites. Nonetheless, as technology of methylation profiling matures over recent years, many studies could now report genome wide methylation status of HCC at single-nucleotide resolution (Table 2). These studies mainly used the beadarray technology developed by Illumina ${ }^{\circ}$. As shown in Table 2 , the most recent studies by Song et al., Zhang et al. and Shen et al. reported the mapping of more than $485000 \mathrm{CpG}$ sites, the highest throughput so far, in HCC.

Genome wide methylation profiling provides wealth of information for downstream analysis. Using these high throughput data, researchers could efficiently separate tumors from adjacent non-tumors [39-47], cirrhotic liver from HCC $[48,49]$, and cluster the tumors according to their risk factors such as viral infection $[38,43,46]$ and alcohol consumption $[42,43]$. Novel tumor suppressor genes that were silenced by methylation could also be uncovered through genome wide studies, as shown by studies in [37,50-53]. As reports on genome wide methylation profile of HCC patients using serum DNA begin to emerge $[41,42]$, it is hoped that these high throughput data could accelerate the process of biomarker discovery.

\section{Methylation as prognostic marker}

From 2003 to 2013, many studies have published on the prognostic values of DNA methylation in HCC. These studies are summarized in Additional file 1: Table S1. Due to space constraints, within this review, only a few examples will be highlighted. One of the early studies was reported by Yang et al. Their group profiled methylation status of 9 genes, namely GSTP1, SOCS1, CDH1, APC, p15, p16, p14, p73 and RAR- $\beta$ in 51 HCC samples using methylation-specific polymerase chain reaction (MSP) [54]. Among these genes, methylation of SOCS1, APC and p15 were shown to be more frequently observed in $\mathrm{HCV}$-positive $\mathrm{HCC}$ patients compared to $\mathrm{HBV} / \mathrm{HCV}$ negative HCC. Another group from Korea, Lee et al. examined the methylation level of CpG loci in 14 genes in sixty HCC paired samples and found that methylation of GSTP1 and CDH1 were associated with poorer overall survival [55]. Similarly, Yu et al. used MSP to identify methylation level of 24 genes in 28 HCC samples from a Chinese population. They successfully showed that methylation of AR, DBCCR1, IRF7, OCT6, p73, and p16 were associated with late stage HCC [56]. These three studies laid a strong basis for subsequent methylation analysis. Many studies have since then attempted to associate clinical parameters with DNA methylation, particularly on genes that were validated in these three studies. Subsequent paragraphs will outline 4 of these genes, namely, p16, SOCS1, GSTP1 and CDH1 (Table 3).

\section{Commonly studied methylation marker genes}

p16 (CDKN2A) is one of the most reported genes that was shown to be hypermethylated and associated with clinical parameters in HCC. It is a tumor suppressor gene that plays a role in cell cycle regulation [57]. It was methylated in many other cancers as well [58]. Beside earlier study by $\mathrm{Yu}$ et al. [56], Shim et al. [59] and Su et al. [60] also reported that methylation level of p16 was associated with advanced stage of HCC. They showed that methylation of p16 gene increased from cirrhotic tissue to HCC. Studies have also shown that hepatitis virus positive HCC samples have higher p16 methylation compared to $\mathrm{HCC}$ with no viral infection [61-64]. Zhu et al. even further showed that HBx gene, a protein coded by HBV, was associated with methylation of p16 in HBV positive HCC samples [65]. Clearly, environment factors such as viral infection could possibly disturb the epigenetic profile of the liver and contribute towards carcinogenesis. In addition, vascular invasion [61] and tumor differentiation [66] were also shown to be associated with p16 methylation. As vascular invasiveness and tumor differentiation were both strong predictors of survival in HCC [67-69], it is not surprising that hypermethylation of p16 in HCC patients was shown to have worse disease free survival as well [70].

Another frequently studied prognostic marker is SOCS1 methylation. SOCS1 gene was shown to be negative regulator of JAK/STAT pathway and its suppression by hypermethylation promotes cell growth [71]. SOCS1 methylation was correlated with progression of HCC [72], age [73,74] and tumor size [73,75]. Moreover, as mentioned in earlier paragraph, SOCS1 methylation was shown by Yang et al. to be associated with HCV infected HCC [54]. Concurring their study, Nishida et al. [76] and Ko et al. [73] also revealed that SOCS1 methylation was more prevalent in HCV infected HCC compared to noninfected HCC. Interestingly, Chu et al. [75] and Okochi et al. [77] did not find this association to be significant in their studies; instead, they found liver cirrhosis in HCC to be closely linked to hypermethylation of SOCS1. As HCV infection may lead to liver cirrhosis [78], more studies are required to ascertain this pathological link between $\mathrm{HCV}$ infection, SOCS1 methylation and HCC progression.

GSTP1 belongs to Glutathione S-transferases family, where it plays a role in protecting cells against damage induced by carcinogens, and modulating signal transduction 
Table 2 Genome wide methylation profiling in HCC

\section{Promoter microarray}

\begin{tabular}{|c|c|c|c|c|c|}
\hline Discovery method & HCC patients (n) & Validation method & Validated genes & Publication & Year \\
\hline \multirow[t]{2}{*}{ MCAM-chip } & 10 & Pyrosequencing & RASSF1A, p16, TBX4, MMP14, GNA14, SLC16A5, CCNA1 & Gao et al. [36] & 2008 \\
\hline & 16 & Pyrosequencing & KLHL35, PAX5, PENK, SPDYA, LINE-1 & Shitani et al. [40] & 2012 \\
\hline DMH-chip & 21 & MSP & KLK10, OXGR1 & Lu et al. [37] & 2008 \\
\hline \multirow[t]{2}{*}{ MeDIP-chip } & 6 & MassArray & $\begin{array}{l}\text { CYP24A1, DLX1, ZNF141, RASGRF2, ZNF382, TUBB6, NPR1, } \\
\text { RRAD, RUNX3, LOX, JAKMIP1, SFRP4, DUSP4, PARQ8, CYP7B1 }\end{array}$ & Deng et al. [38] & 2010 \\
\hline & 11 & Pyrosequencing & AKR1B10, CENPH, MMP9, MMP12, PAGE4, S100A5, MMP2, NUPR1 & Stefanska et al. [39] & 2011 \\
\hline
\end{tabular}

\begin{tabular}{|c|c|c|c|c|c|}
\hline & 11 & Pyrosequencing & AKR1B10, CENPH, MMP9, MMP12, PAGE4, S100A5, MMP2, NUPR1 & Stefanska et al. [39] & 2011 \\
\hline \multicolumn{6}{|l|}{ Beadarray } \\
\hline Discovery method & HCC patients ( $n$ ) & Validation method & Validated genes & Publication & Year \\
\hline \multirow[t]{3}{*}{ GoldenGate } & 20 & Methylight assay & APC & Archer et al. [49] & 2010 \\
\hline & 38 & Pyrosequencing & RASSF1, GSTP1, APC, GABRA5, LINE-1 & Hernandez-Vargas et al. [43] & 2010 \\
\hline & 45 & Bisulfite sequencing & ERG, HOXA9 & Hou et al. [47] & 2013 \\
\hline \multirow[t]{6}{*}{ Infinium 27K } & 3 & COBRA and bisulfite sequencing & WNK2, EMILIN2, TLX3, TM6SF1, TRIM58, HIST1H4F, GRASP & Tao et al. [44] & 2011 \\
\hline & 62 & NIL & NIL & Yang et al. [118] & 2011 \\
\hline & 13 & NIL & NIL & Ammerpohl et al. [48] & 2012 \\
\hline & 62 & Pyrosequencing & CDKL2, STEAP4, HIST1H3G, CDKN2A, ZNF154 & Shen et al. [42] & 2012 \\
\hline & 63 & Pyrosequencing & PER3 & Neumann et al. [50] & 2012 \\
\hline & 71 & Pyrosequencing & NEFH, SMPD3 & Revill et al. [53] & 2013 \\
\hline \multirow[t]{3}{*}{ Infinium 450K } & 66 & $\mathrm{NIL}$ & NIL & Shen et al. [46] & 2013 \\
\hline & 27 & Pyrosequencing & GSTP1, RASSF1, BMP4, DLGAP1, GPR35 & Song et al. [45] & 2013 \\
\hline & 6 & Bisulfite sequencing & DBX2, THY1 & Zhang et.al. [41] & 2013 \\
\hline
\end{tabular}

COBRA, Combined bisulfite restriction analysis; MSP, Methylation specific PCR. 
Table 3 Commonly studied methylation markers in HCC

\begin{tabular}{|c|c|c|c|c|c|}
\hline Gene & HCC patients (n) & Clinicopathological correlation & Validation method & Publication & Year \\
\hline \multirow[t]{10}{*}{ p16 } & 28 & Tumor stage & MSP & Yu et al. [56] & 2003 \\
\hline & 18 & Tumor stage & MSP & Shim et al. [59] & 2003 \\
\hline & 20 & Tumor differentiation & MSP & Qin et al. [66] & 2004 \\
\hline & 50 & Age, gender, virus infection (HBV/HCV) & MSP & Li et al. [62] & 2004 \\
\hline & 44 & HBV infection & MSP & Jicai et al. [63] & 2006 \\
\hline & 60 & Age, tumor stage, vascular invasion, virus infection (HBV/HCV) & MSP & Katoh et al. [61] & 2006 \\
\hline & 58 & Tumor stage & MSP & Su et al. [60] & 2007 \\
\hline & 23 & HBV infection (HBx) & MSP & Zhu et al. [65] & 2007 \\
\hline & 265 & Disease free survival & MSP & Ko et al. [70] & 2008 \\
\hline & 118 & Gender & Methylscreen & Wang et al. [119] & 2012 \\
\hline \multirow[t]{8}{*}{ SOCS1 } & 50 & Liver cirrhosis & MSP & Okochi et al. [77] & 2003 \\
\hline & 51 & HCV infection & MSP & Yang et al. [54] & 2003 \\
\hline & 284 & Age, tumor size, virus infection (HBV/HCV) & MSP & Ko et al. [73] & 2008 \\
\hline & 77 & HCV infection & COBRA & Nishida et al. [76] & 2008 \\
\hline & 46 & Liver cirrhosis, tumor size & MSP & Chu et al. [75] & 2010 \\
\hline & 46 & Tumor stage & MethyLight & Um et al. [72] & 2011 \\
\hline & 29 & Chemotherapy treatment & MSP & Saelee et al. [120] & 2012 \\
\hline & 116 & Age and gender & Methylscreen & Zhang et al. [74] & 2013 \\
\hline \multirow[t]{6}{*}{ GSTP1 } & 60 & Overall survival & MSP & Lee et al. [55] & 2003 \\
\hline & 83 & Alcohol consumption, gender & MSP & Zhang et al. [82] & 2005 \\
\hline & 60 & Gender, viral infection (HBV/HCV) & MSP & Katoh et al. [61] & 2006 \\
\hline & 58 & HBV infection, tumor stage & MSP & Su et al. [60] & 2007 \\
\hline & 77 & HCV infection & COBRA & Nishida et al. [76] & 2008 \\
\hline & 166 & HBV infection & Pyrosequencing & Lambert et al. [81] & 2011 \\
\hline \multirow[t]{2}{*}{$\mathrm{CDH} 1$} & 60 & Overall survival & MSP & Lee et al. [55] & 2003 \\
\hline & 32 & Vascular invasion, recurrence & MSP & Ghee [91] & 2005 \\
\hline
\end{tabular}

COBRA, Combined Bisulfite Restriction Analysis; $H B V$, Hepatitis B virus; $H C V$, Hepatitis C virus; $H B x$, Hepatitis B virus X protein; MSP, Methylation-specific PCR.

pathways that control cell proliferation and cell death [79]. Promoter methylation of GSTP1 was first reported in prostatic carcinoma back in 1994 [80]. Since then, many groups reported such observation in other cancers, including HCC. Analogous to earlier mentioned two genes, GSTP1 was also found to be highly methylated in HCC infected with either HBV or HCV compared to noninfected HCC $[60,61,76,81]$. Interestingly, methylation of GSTP1 was significantly associated with gender $[61,82]$ and alcohol intake [82]. Also, study by Lee et al. managed to show that patients with high GSTP1 methylation level have worse overall survival outcome [55]. Although many studies examined the association of GSTP1 methylation with clinicopathological characteristics, only a few found associations suggesting that GSTP1 methylation alone may not be sufficient to serve as good single prognostic predictor for $\mathrm{HCC}$.

CDH1 is another well-known tumor suppressor gene that was found methylated in many cancers [83-88]. It was frequently methylated in HCC as well. Despite many studies showed that methylation of $\mathrm{CDH} 1$ was higher in $\mathrm{HCC}$ than adjacent non-tumors, it often was not significantly associated with clinical parameters $[54,61,76,89,90]$. Only Lee et al. reported that methylation of CDH1 was linked with worse overall survival [55], and Ghee et al. found that it was associated with vascular invasion and recurrence [91]. These reports suggest that probably CDH1 alone may not have the power to be an independent prognostic factor. Notably, the concurrent methylation of CDH1, GSTP1 and a few other genes were found to be significantly associated with levels of AFP, recurrence free survival (RFS) and tumor numbers (Table 4). This concordant methylation of a group of genes associated with specific tumor characteristics is known as CIMP or CpG island methylator phenotype [92]. Presently, many studies have attempted to elucidate CIMP in various cancers, including G-CIMP for gliomas [93], B-CIMP for breast cancer [94], and C-CIMP for colorectal cancer [95]. In $\mathrm{HCC}$, concurrent methylation of various genes has been associated with various clinical phenotypes (Table 4) and 
Table 4 CIMP studies in HCC

\begin{tabular}{|c|c|c|c|c|c|}
\hline Genes used to define CIMP & HCC patients (n) & $\begin{array}{l}\text { Clinicopathological } \\
\text { correlation }\end{array}$ & $\begin{array}{l}\text { Validation } \\
\text { method }\end{array}$ & Publication & Year \\
\hline $\begin{array}{l}\text { ER, c-MYC, p14, p15, p16, p53, RB1, } \\
\text { RASSF1A, WT1 }\end{array}$ & 50 & AFP level & MSP & Zhang et al. [96] & 2007 \\
\hline $\begin{array}{l}\text { E2F1, p15, p16, p21, p27, p300, p53, } \\
\text { RB, WT1 }\end{array}$ & 120 & Metastasis & MSP & Zhang et al. [97] & 2008 \\
\hline $\begin{array}{l}\text { CDH1, p14, p15, p16, p21, RB1, RASSF1A, } \\
\text { SYK, TIMP3, WT1 }\end{array}$ & 60 & Metastasis, tumor stage & MSP & Cheng et al. [98] & 2010 \\
\hline CDH1, DAPK, GSTP1, p16, SOCS1, SYK, XAF1 & 65 & AFP, RFS, tumor numbers & MSP & Wu et al. [100] & 2010 \\
\hline $\begin{array}{l}\text { GSTP1, MGMT, OPCML, p14, p15, p16, p73, } \\
\text { RARß, SOCS1 }\end{array}$ & 115 & OS, RFS & MSP & Li et al. [99] & 2010 \\
\hline APC, CDH1, DKK, DLC1, RUNX3, SFRP1, WIF1 & 108 & $\begin{array}{l}\text { AFP level, DFS, Gender, HBV status, } \\
\text { tumor stage }\end{array}$ & MSP & Liu et al. [101] & 2011 \\
\hline $\begin{array}{l}\text { APC, GSTP1, HIC1, p16, PRDM2, RASSF1A, } \\
\text { RUNX3, SOCS1 }\end{array}$ & 177 & DFS & Methylight & Nishida et al. [102] & 2012 \\
\hline
\end{tabular}

AFP, Alpha fetoprotein; DFS, Disease free survival; HBV, Hepatitis B virus; MSP, Methylation-specific PCR; OS, Overall survival; RFS, Recurrence free survival.

these could perhaps be known as $\mathrm{CpG}$ island methylator phenotype for hepatocellular carcinoma, or Hep-CIMP.

Hep-CIMP associated with clinicopathological parameters Presently, almost all studies that attempt to characterize Hep-CIMP came from Chinese population and methylation level of these CIMP genes were determined by MSP method. L-X, Wei led a team that published three studies on Hep-CIMP from 2007 to 2010. They defined CIMP + as samples with five or more methylated marker genes. Interestingly, marker genes that they used to define CIMP status varied across three studies (Table 4). Nonetheless, they managed to associate CIMP status with elevated AFP level (AFP $\geq 30 \mu \mathrm{g} / \mathrm{L}$ ) [96], tumor metastasis [97,98], telomerase activity [97], tumor-node-metastasis (TNM) staging and overall survival [98].

$\mathrm{Li}$ et al. on the other hand, examined the methylation status of nine marker genes, namely, p14, p15, p16, p73, GSTP1, MGMT, RAR $\beta$, SOCS-1, and OPCML in 115 tumors. They defined CIMP + as HCC samples with six or more such methylated genes. They showed that CIMP + patients with TNM stage I have significantly poorer recurrence-free survival (RFS) and overall survival (OS) compared to CIMP-, TNM stage I patients [99]. Wu et al. also reported similar observation, despite their definition of CIMP + differed slightly [100]. They considered a sample to be CIMP + as long as it has three or more methylated marker genes. Their study revealed that CIMP + patients have shorter RFS compared to CIMP- patients. On top of that, they also showed that tumor number and pre-operative AFP levels were significantly higher in CIMP + samples [100].

More recently, Liu et al. reported the CIMP status of 108 HCC tissues and plasma respectively, based on methylation level of seven marker genes (Table 4). They found good concordance of methylation status between plasma and tissue samples. CIMP status in tumor tissues and plasma were both significantly associated with clinicopathological parameters such as AFP level, TNM staging, gender and HBV infection [101]. Lastly, Nishida et al. profiled methylation status of eight genes, namely, HIC1, SOCS1, GSTP1, p16, APC, RASSF1, PRDM2 and RUNX3, and found that these markers, collectively, were associated with shorter time-to-occurrence of HCC tumor [102]. Even though Nishida et al. did not report CIMP status in their study, their analysis was similar to the rest of the Hep-CIMP studies. Also worthy to note is that these markers were carefully selected to represent very early stage of HCC. This again emphasizes the potential clinical use of early CIMP + signature for diagnosis or prognosis purposes.

Currently, there is still no consensus on how we define CIMP for HCC. As mentioned previously, all studies determined CIMP status based on their own set of genes, even though we saw a few recurrent genes such as GSTP1 and p16. This is partly due to the technology limitation in the past as most studies used MSP for methylation profiling. With genome-wide profiling methods become more available, it is a matter of time that we can soon ascertain the methylation markers that make up Hep-CIMP.

\section{DNA methylation as potential blood biomarker}

$\mathrm{HCC}$ is associated with high mortality rate mainly due to late diagnosis [1]. Therefore, there is an urgent need to identify promising tool that could diagnose the disease early or be served as surveillance for patients at risk. DNA methylation profile derived from blood samples could potentially be such biomarker. The attempt to identify methylation marker in blood dated back as early as 2003, where Wong et al. used quantitative MSP to measure the 
Table 5 Methylation studies on DNA extracted from HCC blood samples

\section{With clinicopathological correlation}

\begin{tabular}{|c|c|c|c|c|c|c|}
\hline Marker genes & HCC patients (n) & Clinicopathological correlation & Validation method & Samples used for DNA extraction & Publication & Year \\
\hline DAPK, p16 & 64 & AFP level & MSP & Serum & Lin et al. [104] & 2005 \\
\hline RASSF1A & 40 & Tumor size & MSP & Plasma & Yeo et al. [106] & 2005 \\
\hline LINE-1 & 85 & OS, tumor size & COBRA & Serum & Tangkijvanich et al. [109] & 2007 \\
\hline RASSF1A & 85 & DFS & Methylscreen & Serum & Chan et al. [107] & 2008 \\
\hline CCND2 & 70 & DFS & qMSP & Serum & Tsutsui et al. [105] & 2010 \\
\hline $\begin{array}{l}\text { APC, DKK, DLC1, CDH1, RUNX3, } \\
\text { SFRP1, WIF1 }\end{array}$ & 108 & $\begin{array}{l}\text { CIMP + associated with gender, HBV infection, } \\
\text { AFP level, tumor stage, DFS }\end{array}$ & MSP & Plasma & Liu et al. [101] & 2011 \\
\hline APC, GSTP1, RASSF1A, SFRP1 & 72 & OS (APC, RASSF1A) & Methylscreen & Plasma & Huang et al. [108] & 2011 \\
\hline LINE-1 & 305 & Increased risk of HCC & Pyrosequencing & White blood cells & Wu et al. [110] & 2012 \\
\hline IGFBP7 & 136 & Vascular invasion & MSP & Serum & Li et al. [115] & 2013 \\
\hline $\mathrm{XPO4}$ & 44 & AFP level & MSP & PBMC & Zhang et al. [114] & 2013 \\
\hline TFPI2 & 43 & Tumor stage & MSP & Serum & Sun et al. [113] & 2013 \\
\hline APC & 23 & Portal vein thrombosis & qMSP & Serum & Nishida et al. [112] & 2013 \\
\hline \multicolumn{7}{|c|}{ Without clinicopathological correlation } \\
\hline Marker genes & HCC patients (n) & Clinicopathological correlation & Validation method & Samples used for DNA extraction & Publication & Year \\
\hline p16 & 29 & $\mathrm{NIL}$ & qMSP & Serum and buffy coat & Wong et al. [103] & 2003 \\
\hline p16 & 46 & $\mathrm{NIL}$ & MSP & Serum & Chu et al. [121] & 2004 \\
\hline GSTP1 & 32 & $\mathrm{NIL}$ & MSP & Serum & Wang et al. [122] & 2006 \\
\hline CDH1, p16, RASSF1A, RUNX3 & 8 & $\mathrm{NIL}$ & MSP & Serum & Tan et al. [123] & 2007 \\
\hline p16, p15, RASSF1A & 50 & $\mathrm{NIL}$ & MSP & Serum & Zhang et al. [124] & 2007 \\
\hline GSTP1, RASSF1A & 26 & $\mathrm{NIL}$ & MSP & Serum & Chang et al. [125] & 2008 \\
\hline RASSF1A & 35 & $\mathrm{NIL}$ & MSP & Serum & Hu et al. [126] & 2010 \\
\hline APC, CDH1, FHIT, p15, p16 & 28 & $\mathrm{NIL}$ & MSP & Plasma & lyer et al. [127] & 2010 \\
\hline DBX2, THY1 & 31 & NIL & Bisulfite seq & PBMC & Zhang et al. [41] & 2013 \\
\hline
\end{tabular}

AFP, Alpha fetoprotein; COBRA, Combined Bisulfite Restriction Analysis; DFS, Disease free survival; HBV, Hepatitis B virus; MSP, Methylation-specific PCR; $q M S P$, Quantitative MSP; OS, Overall survival; PBMC, Peripheral blood mononuclear cells; Seq, Sequencing. 
methylation status of p16 in 29 HCC patients [103]. However, they did not perform any clinical association with their data. In fact, many studies successfully measure the aberrant methylation level of a marker gene in blood but did not associate it with clinicopathological parameters. These studies can be found in Table 5 .

In this section, we will only highlight reports with significant clinical association. As shown in Table 5, Lin et al. showed that among 64 patients, about $77 \%$ of them have p16 methylation and $41 \%$ of them have DAPK methylation. Both markers were associated with AFP levels but no other parameters [104]. Tsutsui et al. found that the serum of 39 out of 70 patients were positive for methylated CCND2 gene. Patients of this group had shorter disease free survival [105].

Yeo et al. used MSP and found that 17 out of 40 patients' plasma (42.5\%) had RASSF1A hypermethylation and their methylation status was associated with tumor size [106]. Chan et al. used another method, methylationsensitive restriction enzyme-mediated real-time PCR system, to detect RASSF1A methylation status in 85 HCC sera. They found that $93 \%$ of them have hypermethylation and their methylated status was associated with shorter disease free survival and time-to-occurrence for HCC [107]. Using similar detection method, Huang et al. also showed that RASSF1A gene in 72 patients' blood was hypermethylated compared to normal controls and that its methylation level was associated with poorer overall survival [108].

Tangkijvanich et al. used Combined Bisulfite Restriction Analysis (COBRA) method to measure the hypomethylation of LINE-1 in 85 patients' sera. They reported that hypomethylation of LINE-1 was associated with HBV infection, larger tumor size and more advance disease stage [109]. Their study was further validated by Wu et al., where they used pyrosequencing to determine the methylation level of LINE-1 in 305 patients' white blood cell DNA [110]. They used logistic regression model to show that hypomethylation of LINE-1 increased overall risk of developing HCC. Recently, Gao et al. also reported that LINE-1 was hypomethylated in $71 \mathrm{HCC}$ tissues and was associated with poorer prognosis [111]. These are few studies that showed hypomethylation instead of hypermethylation as potential prognostic biomarker.

Following the availability of genome-wide methylation profile, we also saw a sudden surge of methylation studies based on patients' sera. Within year 2013, four studies reported prognostic value of four different hypermethylated genes. Briefly, Nishida et al. performed quantitative MSP and showed that APC was more methylated in $23 \mathrm{HCC}$ sera compared to healthy volunteers. They also showed that patients with higher APC methylation were associated with portal vein thrombosis [112]. Sun et al. detected TFPI 2 to be more methylated in 43 HCC sera and its level was associated with TNM stage [113]. Zhang et al. on the other hand found XPO4 to be frequently methylated in 44 patients' peripheral blood mononuclear cells. Their data indicated that higher XPO4 methylation was associated with higher AFP level [114]. Lastly, Li et al. discovered that in HBV-associated HCC, IGFBP7 was more methylated compared to chronic hepatitis $\mathrm{B}$ patients and normal controls. Also, its methylation status was associated with vascular invasion in HCC [115].

Clearly, methylation of marker gene in $\mathrm{HCC}$ blood DNA has potential prognostic value as shown by its association with clinicopathological data. However, most current studies drawn conclusion from a retrospective cohort. In order to translate these markers into actual clinical use, proper prospective studies and validation method are required.

\section{Conclusions}

Many genome wide methylation studies have confirmed that HCC has distinct methylation profile (Table 2), and some even showed that it is associated with different etiological factors such as HBV infection and alcohol consumption. Undeniably, the availability of these genome wide data has allowed the discovery of many novel genes with aberrant methylation, especially in recent years. As shown in Additional file 1: Table S1, apart from the commonly studied genes mentioned in this review, there is plethora of genes that were differentially methylated and associated with clinicopathological data. Future studies need to focus on collating current available data, shortlisting potential methylation markers by conducting proper validation method [116,117] and defining well-characterized CIMP status of HCC. It is hoped that emerging methylation markers can be used as diagnostic or prognostic marker for HCC in near future.

\section{Additional file}

Additional file 1: Table S1. List of methylation studies on HCC from year 2003-2013.

\section{Abbreviations}

AFP: Alpha fetoprotein; CIMP: CpG island methylator phenotype; COBRA: Combined bisulfite restriction analysis; DFS: Disease free survival; DMH-chip: Differential methylation hybridization on microarray; DNMT: DNA methyltransferase; HBV: Hepatitis B virus; HBx: Hepatitis B virus X protein; HCC: Hepatocellular Carcinoma; HCV: Hepatitis C virus; MCAM: Methylated CpG island amplification microarray; MeDIP-Chip: Methylated DNA immunoprecipitation microarray; MSP: Methylation-specific PCR; OS: Overall survival; PBMC: Peripheral blood mononuclear cells; PCR: Polymerase chain reaction; QMSP: Quantitative MSP; RFS: Recurrence free survival.

\section{Competing interests}

All authors declare that they have no conflicts of interests.

\section{Authors' contributions}

CGL and W-C researched data and wrote the manuscript. Both authors read and approved the final manuscript. 


\section{Acknowledgements}

This work is supported by grants from the National Medical Research Council (NMRC) (NMRC/1131/2007 and NMRC/1238/2009), the BioMedical Research Council (BMRC) (BMRC06/1/21/19/449) of Singapore and the Singapore Millennium Foundation (SMF) as well as block fundings from the National Cancer Centre, SINGAPORE and the DUKE-NUS Graduate Medical School to A/Prof Caroline Lee.

\section{Author details}

'Department of Biochemistry, Yong Loo Lin School of Medicine, National University of Singapore, Singapore 117597, Singapore. 'Division of Medical Sciences, Humphrey Oei Institute of Cancer Research, National Cancer Centre Singapore, Level 6, Lab 5, 11 Hospital Drive, Singapore 169610, Singapore. ${ }^{3}$ NUS Graduate School for Integrative Sciences and Engineering, National University of Singapore, Singapore 117456, Singapore. ${ }^{4}$ Duke-NUS Graduate Medical School, Singapore 169857, Singapore.

Received: 2 February 2014 Accepted: 7 March 2014

Published: 17 March 2014

\section{References}

1. Jemal A, Bray F, Center MM, Ferlay J, Ward E, Forman D: Global cancer statistics. CA Cancer J Clin 2011, 61(2):69-90.

2. Villanueva A, Minguez B, Forner A, Reig M, Llovet JM: Hepatocellular carcinoma: novel molecular approaches for diagnosis, prognosis, and therapy. Annu Rev Med 2010, 61:317-328.

3. Hoofnagle $\mathrm{JH}$ : Hepatocellular carcinoma: summary and recommendations. Gastroenterology 2004, 127(5 Suppl 1):S319-S323.

4. Yang JD, Roberts LR: Hepatocellular carcinoma: a global view. Nat Rev Gastroenterol Hepatol 2010, 7(8):448-458.

5. Poon D, Anderson BO, Chen LT, Tanaka K, Lau WY, van Cutsem E, Singh $H$, Chow WC, Ooi LL, Chow P, Khin MW, Koo WH: Management of hepatocellular carcinoma in Asia: consensus statement from the Asian Oncology Summit 2009. Lancet Oncol 2009, 10(11):1111-1118.

6. Colli A, Fraquelli M, Casazza G, Massironi S, Colucci A, Conte D, Duca P: Accuracy of ultrasonography, spiral CT, magnetic resonance, and alpha-fetoprotein in diagnosing hepatocellular carcinoma: a systematic review: CME. Am J Gastroenterol 2006, 101(3):513-523.

7. Terentiev AA, Moldogazieva NT: Alpha-fetoprotein: a renaissance. Tumour Biol 2013, 34(4):2075-2091.

8. Song P, Tobe RG, Inagaki Y, Kokudo N, Hasegawa K, Sugawara Y, Tang W: The management of hepatocellular carcinoma around the world: a comparison of guidelines from 2001 to 2011. Liver Int 2012, 32(7):1053-1063.

9. Llovet JM, Bru C, Bruix J: Prognosis of hepatocellular carcinoma: the BCLC staging classification. Semin Liver Dis 1999, 19(3):329-338.

10. Borel F, Konstantinova P, Jansen PLM: Diagnostic and therapeutic potential of miRNA signatures in patients with hepatocellular carcinoma. $J$ Hepatol 2012, 56(6):1371-1383.

11. Budhu A, Jia HL, Forgues M, Liu CG, Goldstein D, Lam A, Zanetti KA, Ye QH Qin LX, Croce CM, Tang ZY, Xin WW: Identification of metastasis-related microRNAs in hepatocellular carcinoma. Hepatology 2008, 47(3):897-907.

12. Hoshida Y, Nijman SMB, Kobayashi M, Chan JA, Brunet JP, Chiang DY, Villanueva A, Newell P, Ikeda K, Hashimoto M, Watanabe G, Gabriel S, Friedman SL, Kumada H, Llovet JM, Golub TR: Integrative transcriptome analysis reveals common molecular subclasses of human hepatocellular carcinoma. Cancer Res 2009, 69(18):7385-7392.

13. Lee JS, Thorgeirsson SS: Genome-scale profiling of gene expression in hepatocellular carcinoma: classification, survival prediction, and identification of therapeutic targets. Gastroenterology 2004, 127(SUPPL):S51-S55.

14. Lemmer ER, Friedman SL, Llovet JM: Molecular diagnosis of chronic liver disease and hepatocellular carcinoma: the potential of gene expression profiling. Semin Liver Dis 2006, 26(4):373-384.

15. Villanueva A, Hoshida Y, Battiston C, Tovar V, Sia D, Alsinet C, Cornella H, Liberzon A, Kobayashi M, Kumada H, Thung SN, Bruix J, Newell P, April C, Fan J, Roayaie S, Mazzaferro V, Schwartz ME, Llovet JM: Combining clinical, pathology, and gene expression data to predict recurrence of hepatocellular carcinoma. Gastroenterology 2011, 140(5):1501-1512. e1502.

16. Minouchi K, Kaneko S, Kobayashi K: Mutation of p53 gene in regenerative nodules in cirrhotic liver. J Hepatol 2002, 37(2):231-239.
17. Bressac B, Kew M, Wands J, Ozturk M: Selective G to T mutations of p53 gene in hepatocellular carcinoma from southern Africa. Nature 1991, 350(6317):429-431

18. Ishizaki Y, Ikeda S, Fujimori M, Shimizu Y, Kurihara T, Itamoto T, Kikuchi A Okajima M, Asahara T: Immunohistochemical analysis and mutational analyses of beta-catenin, Axin family and APC genes in hepatocellular carcinomas. Int J Oncol 2004, 24(5):1077-1083.

19. Edamoto Y, Hara A, Biernat W, Terracciano L, Cathomas G, Riehle HM, Matsuda M, Fujii H, Scoazec JY, Ohgaki H: Alterations of RB1, p53 and Wnt pathways in hepatocellular carcinomas associated with hepatitis $C$ hepatitis B and alcoholic liver cirrhosis. Int J Cancer 2003, 106(3):334-341.

20. Satoh S, Daigo Y, Furukawa Y, Kato T, Miwa N, Nishiwaki T, Kawasoe T, Ishiguro H, Fujita M, Tokino T, Sasaki Y, Imaoka S, Murata M, Shimano T, Yamaoka Y, Nakamura Y: AXIN1 mutations in hepatocellular carcinomas, and growth suppression in cancer cells by virus-mediated transfer of AXIN1. Nat Genet 2000, 24(3):245-250

21. Taniguchi K, Roberts LR, Aderca IN, Dong X, Qian C, Murphy LM, Nagorney DM, Burgart LJ, Roche PC, Smith DI, Ross JA, Liu W: Mutational spectrum of beta-catenin, AXIN1, and AXIN2 in hepatocellular carcinomas and hepatoblastomas. Oncogene 2002, 21(31):4863-4871.

22. Han ZG: Functional genomic studies: insights into the pathogenesis of liver cancer. Annu Rev Genom Hum G 2012, 13:171-205.

23. Pradhan S, Bacolla A, Wells RD, Roberts RJ: Recombinant human DNA (cytosine-5) methyltransferase. I. Expression, purification, and comparison of de novo and maintenance methylation. J Biol Chem 1999, 274(46):33002-33010.

24. Feinberg AP, Vogelstein B: Hypomethylation distinguishes genes of some human cancers from their normal counterparts. Nature 1983, 301(5895):89-92.

25. Tischoff I, Tannapfel A: DNA methylation in hepatocellular carcinoma. World J Gastroentero 2008, 14(11):1741-1748.

26. Park IY, Sohn BH, Yu E, Suh DJ, Chung Y, Lee J, Surzycki SJ, Lee Yl: Aberrant epigenetic modifications in hepatocarcinogenesis induced by hepatitis $B$ virus X protein. Gastroenterology 2007, 132(4):1476-1494.

27. Lim JS, Park SH, Jang KL: Hepatitis C virus core protein overcomes stress-induced premature senescence by down-regulating $\mathrm{p} 16$ expression via DNA methylation. Cancer Lett 2012, 321(2):154-161.

28. Arora P, Kim EO, Jung JK, Jang KL: Hepatitis $C$ virus core protein downregulates E-cadherin expression via activation of DNA methyltransferase 1 and $3 \mathrm{~b}$. Cancer Lett 2008, 261(2):244-252.

29. Nagai M, Nakamura A, Makino R, Mitamura K: Expression of DNA (5-cytosin)methyltransferases (DNMTs) in hepatocellular carcinomas. Hepatol Res 2003, 26(3):186-191.

30. Park HJ, Yu E, Shim YH: DNA methyltransferase expression and DNA hypermethylation in human hepatocellular carcinoma. Cancer Lett 2006, 233(2):271-278.

31. Bibikova M, Le J, Barnes B, Saedinia-Melnyk S, Zhou L, Shen R, Gunderson KL: Genome-wide DNA methylation profiling using Infinium(R) assay. Epigenomics 2009, 1(1):177-200.

32. Touleimat N, Tost J: Complete pipeline for Infinium((R)) Human Methylation $450 \mathrm{~K}$ BeadChip data processing using subset quantile normalization for accurate DNA methylation estimation. Epigenomics 2012, 4(3):325-341.

33. Estécio MRH, Yan PS, Ibrahim AEK, Tellez CS, Shen L, Huang THM, Issa JPJ: High-throughput methylation profiling by MCA coupled to CpG island microarray. Genome Res 2007, 17(10):1529-1536.

34. Huang TH, Perry MR, Laux DE: Methylation profiling of CpG islands in human breast cancer cells. Hum Mol Genet 1999, 8(3):459-470.

35. Mohn F, Weber M, Schubeler D, Roloff TC: Methylated DNA immunoprecipitation (MeDIP). Methods Mol Biol 2009, 507:55-64

36. Gao W, Kondo Y, Shen L, Shimizu Y, Sano T, Yamao K, Natsume A, Goto Y, Ito M, Murakami H, Osada H, Zhang J, Issa JPJ, Sekido Y: Variable DNA methylation patterns associated with progression of disease in hepatocellular carcinomas. Carcinogenesis 2008, 29(10):1901-1910.

37. Lu CY, Hsieh SY, Lu YJ, Wu CS, Chen LC, Lo SJ, Wu CT, Chou MY, Huang THM, Chang YS: Aberrant DNA methylation profile and frequent methylation of KLK10 and OXGR1 genes in hepatocellular carcinoma. Genes Chromosomes Cancer 2009, 48(12):1057-1068.

38. Deng YB, Nagae G, Midorikawa Y, Yagi K, Tsutsumi S, Yamamoto S, Hasegawa K, Kokudo N, Aburatani H, Kaneda A: Identification of genes 
preferentially methylated in hepatitis $\mathrm{C}$ virus-related hepatocellular carcinoma. Cancer Sci 2010, 101(6):1501-1510.

39. Stefanska B, Huang J, Bhattacharyya B, Suderman M, Hallett M, Han ZG, Szyf M: Definition of the landscape of promoter DNA hypomethylation in liver cancer. Cancer Res 2011, 71(17):5891-5903.

40. Shitani M, Sasaki S, Akutsu N, Takagi H, Suzuki H, Nojima M, Yamamoto H, Tokino T, Hirata K, Imai K, Toyota M, Shinomura Y: Genome-wide analysis of DNA methylation identifies novel cancer-related genes in hepatocellular carcinoma. Tumor Biol 2012, 33(5):1307-1317.

41. Zhang P, Wen X, Gu F, Deng X, Li J, Dong J, Jiao J, Tian Y: Methylation profiling of serum DNA from hepatocellular carcinoma patients using an Infinium Human Methylation 450 BeadChip. Hepatol Int 2013, 7(3):893-900.

42. Shen J, Wang S, Zhang YJ, Kappil M, Wu HC, Kibriya MG, Wang Q, Jasmine F, Ahsan H, Lee PH, Yu MW, Chen CJ, Santella RM: Genome-wide DNA methylation profiles in hepatocellular carcinoma. Hepatology 2012, 55(6):1799-1808

43. Hernandez-Vargas H, Lambert MP, le Calvez-Kelm F, Gouysse G, McKayChopin S, Tavtigian SV, Scoazec JY, Herceg Z: Hepatocellular carcinoma displays distinct DNA methylation signatures with potential as clinical predictors. PloS One 2010, 5(3):e9749.

44. Tao R, Li J, Xin J, WU J, Guo J, Zhang L, Jiang L, Zhang W, Yang Z, Li L: Methylation profile of single hepatocytes derived from hepatitis B virus-related hepatocellular carcinoma. PLoS One 2011, 6(5):e19862.

45. Song MA, Tiirikainen M, Kwee S, Okimoto G, Yu H, Wong LL: Elucidating the landscape of aberrant DNA methylation in hepatocellular carcinoma. PLoS One 2013, 8(2):e55761.

46. Shen J, Wang S, Zhang YJ, Wu HC, Kibriya MG, Jasmine F, Ahsan H, Wu DPH, Siegel AB, Remotti H, Santella RM: Exploring genome-wide DNA methylation profiles altered in hepatocellular carcinoma using Infinium Human Methylation 450 BeadChips. Epigenetics 2013, 8(1):34-43.

47. Hou X, Peng JX, Hao XY, Cai JP, Liang LJ, Zhai JM, Zhang KS, Lai JM, Yin XY: DNA methylation profiling identifies EYA4 gene as a prognostic molecular marker in hepatocellular carcinoma. Ann Surg Oncol 2013. in press.

48. Ammerpohl O, Pratschke J, Schafmayer C, Haake A, Faber W, von Kampen O, Brosch M, Sipos B, von Schönfels W, Balschun K, Röcken C, Arlt A, Schniewind B, Grauholm J, Kalthoff H, Neuhaus P, Stickel F, Schreiber S, Becker T, Siebert R, Hampe J: Distinct DNA methylation patterns in cirrhotic liver and hepatocellular carcinoma. Int J Cancer 2012, 130(6):1319-1328.

49. Archer KJ, Mas VR, Maluf DG, Fisher RA: High-throughput assessment of CpG site methylation for distinguishing between HCV-cirrhosis and HCV-associated hepatocellular carcinoma. Mol Genet Genomics 2010, 283(4):341-349.

50. Neumann O, Kesselmeier M, Geffers R, Pellegrino R, Radlwimmer B, Hoffmann K, Ehemann V, Schemmer P, Schirmacher P, Bermejo JL, Longerich T: Methylome analysis and integrative profiling of human HCCs identify novel protumorigenic factors. Hepatology 2012, 56(5):1817-1827.

51. Matsumura S, Imoto I, Kozaki Kl, Matsui T, Muramatsu T, Furuta M, Tanaka S, Sakamoto M, Arii S, Inazawa J: Integrative array-based approach identifies MZB1 as a frequently methylated putative tumor suppressor in hepatocellular carcinoma. Clin Cancer Res 2012, 18(13):3541-3551.

52. Okamura $Y$, Nomoto $S$, Hayashi M, Hishida M, Nishikawa $Y$, Yamada S, Fujii T, Sugimoto H, Takeda S, Kodera Y, Nakao A: Identification of the bleomycin hydrolase gene as a methylated tumor suppressor gene in hepatocellular carcinoma using a novel triple-combination array method. Cancer Lett 2011, 312(2):150-157.

53. Revill K, Wang T, Lachenmayer A, Kojima K, Harrington A, Li J, Hoshida Y, Llovet JM, Powers S: Genome-wide methylation analysis and epigenetic unmasking identify tumor suppressor genes in hepatocellular carcinoma. Gastroenterology 2013, 145(6):1424-1435.

54. Yang B, Guo M, Herman JG, Clark DP: Aberrant promoter methylation profiles of tumor suppressor genes in hepatocellular carcinoma. Am J Pathol 2003, 163(3):1101-1107.

55. Lee S, Lee HJ, Kim JH, Lee HS, Jang JJ, Kang GH: Aberrant CpG island hypermethylation along multistep hepatocarcinogenesis. Am J Pathol 2003, 163(4):1371-1378.

56. Yu J, Zhang HY, Ma ZZ, Lu W, Wang YF, Zhu J: Methylation profiling of twenty four genes and the concordant methylation behaviours of nineteen genes that may contribute to hepatocellular carcinogenesis. Cell Res 2003, 13(5):319-333.

57. Liggett WH, Sidransky D: Role of the p16 tumor suppressor gene in cancer. J Clin Oncol 1998, 16(3):1197-1206.

58. Esteller M, Corn PG, Baylin SB, Herman JG: A gene hypermethylation profile of human cancer. Cancer Res 2001, 61(8):3225-3229.

59. Shim YH, Yoon GS, Choi HJ, Chung YH, Yu E: p16 Hypermethylation in the early stage of hepatitis $B$ virus-associated hepatocarcinogenesis. Cancer Lett 2003, 190(2):213-219.

60. Su PF, Lee TC, Lin PJ, Lee PH, Jeng YM, Chen CH, Liang JD, Chiou LL, Huang GT, Lee HS: Differential DNA methylation associated with hepatitis B virus infection in hepatocellular carcinoma. Int J Cancer 2007, 121(6):1257-1264.

61. Katoh H, Shibata T, Kokubu A, Ojima H, Fukayama M, Kanai Y, Hirohashi S: Epigenetic instability and chromosomal instability in hepatocellular carcinoma. Am J Pathol 2006, 168(4):1375-1384.

62. Li X, Hei AM, Sun L, Hasegawa K, Torzilli G, Minagawa M, Takayama T, Makuuchi M: p16INK4A hypermethylation is associated with hepatitis virus infection, age, and gender in hepatocellular carcinoma. Clin Cancer Res 2004, 10(22):7484-7489

63. Jicai Z, Zongtao $Y$, Jun L, Haiping L, Jianmin W, Lihua H: Persistent infection of hepatitis $B$ virus is involved in high rate of p16 methylation in hepatocellular carcinoma. Mol Carcinog 2006, 45(7):530-536.

64. Feng Q, Stern JE, Hawes SE, Lu H, Jiang M, Kiviat NB: DNA methylation changes in normal liver tissues and hepatocellular carcinoma with different viral infection. Exp Mol Pathol 2010, 88(2):287-292.

65. Zhu R, Li BZ, Li H, Ling YQ, Hu XQ, Zhai WR, Zhu HG: Association of p16INK4A hypermethylation with hepatitis $B$ virus $X$ protein expression in the early stage of HBV-associated hepatocarcinogenesis. Pathol Int 2007, 57(6):328-336

66. Qin Y, Liu JY, Li B, Sun ZL, Sun ZF: Association of low p16INK4a and p15INK4b mRNAs expression with their CpG islands methylation with human hepatocellular carcinogenesis. World J Gastroenterol 2004, 10(9):1276-1280.

67. Kikuchi LO, Paranagua-Vezozzo DC, Chagas AL, Mello ES, Alves VA, Farias AQ, Pietrobon R, Carrilho FJ: Nodules less than $20 \mathrm{~mm}$ and vascular invasion are predictors of survival in small hepatocellular carcinoma. J Clin Gastroenterol 2009, 43(2):191-195.

68. Tamura S, Kato T, Berho M, Misiakos EP, O'Brien C, Reddy KR, Nery JR, Burke GW, Schiff ER, Miller J, Tzakis AG: Impact of histological grade of hepatocellular carcinoma on the outcome of liver transplantation. Arch Surg 2001, 136(1):25-30.

69. Jonas S, Bechstein WO, Steinmuller T, Herrmann M, Radke C, Berg T, Settmacher U, Neuhaus P: Vascular invasion and histopathologic grading determine outcome after liver transplantation for hepatocellular carcinoma in cirrhosis. Hepatology 2001, 33(5):1080-1086.

70. Ko E, Kim Y, Kim SJ, Joh JW, Song S, Park CK, Park J, Kim DH: Promoter hypermethylation of the 16 gene is associated with poor prognosis in recurrent early-stage hepatocellular carcinoma. Cancer Epidemiol Biomarkers Prev 2008, 17(9):2260-2267.

71. Yoshikawa H, Matsubara K, Qian GS, Jackson P, Groopman JD, Manning JE, Harris CC, Herman JG: SOCS-1, a negative regulator of the JAK/STAT pathway, is silenced by methylation in human hepatocellular carcinoma and shows growth-suppression activity. Nat Genet 2001, 28(1):29-35.

72. Um TH, Kim H, Oh BK, Kim MS, Kim KS, Jung G, Park YN: Aberrant CpG island hypermethylation in dysplastic nodules and early HCC of hepatitis B virus-related human multistep hepatocarcinogenesis. J Hepatol 2011, 54(5):939-947

73. Ko E, Kim SJ, Joh JW, Park CK, Park J, Kim DH: CpG island hypermethylation of SOCS-1 gene is inversely associated with HBV infection in hepatocellular carcinoma. Cancer Lett 2008, 271(2):240-250.

74. Zhang X, Wang J, Cheng J, Ding S, Li M, Sun S, Zhang L, Liu S, Chen X Zhuang H, Lu F: An integrated analysis of SOCS1 down-regulation in HBV infection-related hepatocellular carcinoma. J Viral Hepat 2013. in press.

75. Chu PY, Yeh CM, Hsu NC, Chang YS, Chang JG, Yeh KT: Epigenetic alteration of the SOCS1 gene in hepatocellular carcinoma. Swiss Med Wkly 2010, 140.

76. Nishida N, Nagasaka T, Nishimura T, Ikai I, Boland CR, Goel A: Aberrant methylation of multiple tumor suppressor genes in aging liver, chronic hepatitis, and hepatocellular carcinoma. Hepatology 2008, 47(3):908-918 
77. Okochi O, Hibi K, Sakai M, Inoue S, Takeda S, Kaneko T, Nakao A: Methylation-mediated silencing of SOCS-1 gene in hepatocellular carcinoma derived from cirrhosis. Clin Cancer Res 2003, 9(14):5295-5298.

78. Freeman AJ, Dore GJ, Law MG, Thorpe M, von Overbeck J, Lloyd AR, Marinos G, Kaldor JM: Estimating progression to cirrhosis in chronic hepatitis C virus infection. Hepatology 2001, 34(4 Pt 1):809-816.

79. Laborde E: Glutathione transferases as mediators of signaling pathways involved in cell proliferation and cell death. Cell Death Differ 2010, 17(9):1373-1380.

80. Lee WH, Morton RA, Epstein Jl, Brooks JD, Campbell PA, Bova GS, Hsieh WS, Isaacs WB, Nelson WG: Cytidine methylation of regulatory sequences near the pi-class glutathione S-transferase gene accompanies human prostatic carcinogenesis. Proc Natl Acad Sci USA 1994, 91(24):11733-11737.

81. Lambert MP, Paliwal A, Vaissière $T$, Chemin I, Zoulim F, Tommasino M, Hainaut P, Sylla B, Scoazec JY, Tost J, Herceg Z: Aberrant DNA methylation distinguishes hepatocellular carcinoma associated with HBV and HCV infection and alcohol intake. J Hepatol 2011, 54(4):705-715.

82. Zhang YJ, Chen Y, Ahsan H, Lunn RM, Chen SY, Lee PH, Chen CJ, Santella RM: Silencing of glutathione S-transferase P1 by promoter hypermethylation and its relationship to environmental chemical carcinogens in hepatocellular carcinoma. Cancer Lett 2005, 221(2):135-143.

83. Chang HW, Chow V, Lam KY, Wei WI, WingYuen AP: Loss of E-cadherin expression resulting from promoter hypermethylation in oral tongue carcinoma and its prognostic significance. Cancer 2002, 94(2):386-392.

84. Kanazawa T, Watanabe T, Kazama S, Tada T, Koketsu S, Nagawa H: Poorly differentiated adenocarcinoma and mucinous carcinoma of the colon and rectum show higher rates of loss of heterozygosity and loss of $\mathrm{E}$-cadherin expression due to methylation of promoter region. Int J Cancer 2002, 102(3):225-229.

85. Graziano F, Arduini F, Ruzzo A, Bearzi I, Humar B, More H, Silva R, Muretto P, Guilford P, Testa E, Mari D, Magnani M, Cascinu S: Prognostic analysis of E-cadherin gene promoter hypermethylation in patients with surgically resected, node-positive, diffuse gastric cancer. Clin Cancer Res 2004, 10(8):2784-2789.

86. Takeno S, Noguchi T, Fumoto S, Kimura Y, Shibata T, Kawahara K: E-cadherin expression in patients with esophageal squamos cell carcinoma: Promoter hypermethylation, Snail overexpression, and clinicopathologic implications. Am J Clin Pathol 2004, 122(1):78-84.

87. Shimamoto T, Ohyashiki JH, Ohyashiki K: Methylation of p15INK4b and E-cadherin genes is independently correlated with poor prognosis in acute myeloid leukemia. Leuk Res 2005, 29(6):653-659.

88. Caldeira JRF, Prando EC, Quevedo FC, Moraes Neto FA, Rainho CA, Rogatto SR: $\mathrm{CDH} 1$ promoter hypermethylation and $\mathrm{E}$-cadherin protein expression in infiltrating breast cancer. BMC Cancer 2006, 6:48.

89. Lim SO, Gu JM, Kim MS, Kim HS, Park YN, Park CK, Cho JW, Park YM, Jung G: Epigenetic changes induced by reactive oxygen species in hepatocellular carcinoma: methylation of the E-cadherin promoter. Gastroenterology 2008, 135(6):2128-2140.

90. Oh BK, Kim H, Park HJ, Shim YH, Choi J, Park C, Park YN: DNA methyltransferase expression and DNA methylation in human hepatocellular carcinoma and their clinicopathological correlation. Int J Mol Med 2007, 20(1):65-73.

91. Ghee YK, Byung CY, Kwang CK, Jae WC, Won SP, Cheol KP: Promoter methylation of E-cadherin in hepatocellular carcinomas and dysplastic nodules. J Korean Med Sci 2005, 20(2):242-247.

92. Hughes LA, Melotte V, de Schrijver J, de Maat M, Smit VT, Bovee JV, French PJ, van den Brandt PA, Schouten $\sqcup$, de Meyer T, van Criekinge W, Ahuja N, Herman JG, Weijenberg MP, van Engeland M: The CpG island methylator phenotype: what's in a name? Cancer Res 2013, 73(19):5858-5868.

93. Noushmehr $\mathrm{H}$, Weisenberger DJ, Diefes K, Phillips HS, Pujara K, Berman BP, Pan F, Pelloski CE, Sulman EP, Bhat KP, Verhaak RG, Hoadley KA, Hayes DN, Perou CM, Schmidt HK, Ding L, Wilson RK, van den Berg D, Shen H, Bengtsson H, Neuvial P, Cope LM, Buckley J, Herman JG, Baylin SB, Laird PW, Aldape K: Identification of a CpG island methylator phenotype that defines a distinct subgroup of glioma. Cancer Cell 2010, 17(5):510-522.

94. Fang F, Turcan S, Rimner A, Kaufman A, Giri D, Morris LG, Shen R, Seshan V, Mo Q, Heguy A, Baylin SB, Ahuja N, Viale A, Massague J, Norton L, Vahdat LT, Moynahan ME, Chan TA: Breast cancer methylomes establish an epigenomic foundation for metastasis. Sci Transl Med 2011, 3(75):75ra25.
95. Toyota M, Ahuja N, Ohe-Toyota M, Herman JG, Baylin SB, Issa JP: CpG island methylator phenotype in colorectal cancer. Proc Natl Acad Sci USA 1999, 96(15):8681-8686.

96. Zhang C, Li Z, Cheng Y, Jia F, Li R, Wu M, Li K, Wei L: CpG island methylator phenotype association with elevated serum a-fetoprotein level in hepatocellular carcinoma. Clin Cancer Res 2007, 13(3):944-952.

97. Zhang C, Guo X, Jiang G, Zhang L, Yang Y, Shen F, Wu M, Wei L: CpG island methylator phenotype association with upregulated telomerase activity in hepatocellular carcinoma. Int J Cancer 2008, 123(5):998-1004.

98. Cheng Y, Zhang C, Zhao J, Wang C, Xu Y, Han Z, Jiang G, Guo X, Li R, Bu X, Wu M, Wei L: Correlation of CpG island methylator phenotype with poor prognosis in hepatocellular carcinoma. Exp Mol Pathol 2010, 88(1):112-117

99. Li B, Liu W, Wang L, Li M, Wang J, Huang L, Huang P, Yuan Y: CpG island methylator phenotype associated with tumor recurrence in tumornode-metastasis stage I hepatocellular carcinoma. Ann Surg Oncol 2010, 17(7):1917-1926.

100. Wu LM, Zhang F, Zhou L, Yang Z, Xie HY, Zheng SS: Predictive value of $\mathrm{CpG}$ island methylator phenotype for tumor recurrence in hepatitis B virus-associated hepatocellular carcinoma following liver transplantation. BMC Cancer 2010, 10:399.

101. Liu JB, Zhang YX, Zhou SH, Shi MX, Cai J, Liu Y, Chen KP, Qiang FL: CpG Island methylator phenotype in plasma is associated with hepatocellular carcinoma prognosis. World J Gastroenterol 2011, 17(42):4718-4724.

102. Nishida N, Kudo M, Nagasaka T, Ikai I, Goel A: Characteristic patterns of altered DNA methylation predict emergence of human hepatocellular carcinoma. Hepatology 2012, 56(3):994-1003.

103. Wong IHN, Zhang J, Lai PBS, Lau WY, Lo YMD: Quantitative analysis of tumor-derived methylated p16INK4a sequences in plasma, serum, and blood cells of hepatocellular carcinoma patients. Clin Cancer Res 2003, 9(3):1047-1052.

104. Lin Q, Chen LB, Tang YM, Wang J: Promoter hypermethylation of p16 gene and DAPK gene in sera from hepatocellular carcinoma (HCC) patients. Chin J Cancer Res 2005, 17(4):250-254.

105. Tsutsui M, lizuka N, Moribe T, Miura T, Kimura N, Tamatsukuri S, Ishitsuka H, Fujita Y, Hamamoto Y, Tsunedomi R, lida M, Tokuhisa Y, Sakamoto K, Tamesa T, Sakaida I, Oka M: Methylated cyclin D2 gene circulating in the blood as a prognosis predictor of hepatocellular carcinoma. Clin Chim Acta 2010, 411(7-8):516-520.

106. Yeo W, Wong N, Wong WL, Lai PBS, Zhong S, Johnson PJ: High frequency of promoter hypermethylation of RASSF1A in tumor and plasma of patients with hepatocellular carcinoma. Liver Int 2005, 25(2):266-272

107. Chan KCA, Lai PBS, Mok TSK, Chan HLY, Ding C, Yeung SW, Lo YMD: Quantitative analysis of circulating methylated DNA as a biomarker for hepatocellular carcinoma. Clin Chem 2008, 54(9):1528-1536.

108. Huang $Z H$, Hu Y, Hua D, Wu YY, Song MX, Cheng ZH: Quantitative analysis of multiple methylated genes in plasma for the diagnosis and prognosis of hepatocellular carcinoma. Exp Mol Pathol 2011, 91(3):702-707.

109. Tangkijvanich P, Hourpai N, Rattanatanyong P, Wisedopas N, Mahachai V, Mutirangura A: Serum LINE-1 hypomethylation as a potential prognostic marker for hepatocellular carcinoma. Clin Chim Acta 2007, 379(1-2):127-133.

110. Wu HC, Wang Q, Yang HI, Tsai W, Chen CJ, Santella RM: Global dna methylation levels in white blood cells as a biomarker for hepatocellular carcinoma risk: a nested case-control study. Carcinogenesis 2012, 33(7):1340-1345

111. Gao XD, Qu JH, Chang XJ, Lu YY, Bai WL, Wang H, Xu ZX, An LJ, Wang CP, Zeng Z, Yang YP: Hypomethylation of long interspersed nuclear element-1 promoter is associated with poor outcomes for curative resected hepatocellular carcinoma. Liver Int 2013. in press.

112. Nishida N, Arizumi T, Takita M, Nagai T, Kitai S, Yada N, Hagiwara S, Inoue T, Minami Y, Ueshima K, Sakurai T, Ida H, Kudo M: Quantification of tumor DNA in serum and vascular invasion of human hepatocellular carcinoma. Oncology 2013, 84(SUPPL.1):82-87.

113. Sun FK, Fan YC, Zhao J, Zhang F, Gao S, Zhao ZH, Sun Q, Wang K. Detection of TFPI2 methylation in the serum of hepatocellular carcinoma patients. Dig Dis Sci 2013, 58(4):1010-1015.

114. Zhang F, Fan YC, Mu NN, Zhao J, Sun FK, Zhao ZH, Gao S, Wang K Exportin 4 gene expression and DNA promoter methylation status in chronic hepatitis B virus infection. J Viral Hepat 2013. in press. 
115. Li F, Fan YC, Gao S, Sun FK, Yang Y, Wang K: Methylation of serum insulin-like growth factor-binding protein 7 promoter in hepatitis B virus-associated hepatocellular carcinoma. Genes Chromosomes Cancer 2014, 53(1):90-97.

116. McShane LM, Altman DG, Sauerbrei W, Taube SE, Gion M, Clark GM: REporting recommendations for tumor MARKer prognostic studies (REMARK). Nat Clin Prac Urol 2005, 2(8):416-422.

117. Bossuyt PM, Reitsma JB, Bruns DE, Gatsonis CA, Glasziou PP, Irwig LM, Lijmer JG, Moher D, Rennie D, de Vet HC: Toward complete and accurate reporting of studies of diagnostic accuracy. The STARD initiative. Am J Clin Pathol 2003, 119(1):18-22.

118. Yang JD, Seol SY, Leem SH, Kim YH, Sun Z, Lee JS, Thorgeirsson SS, Chu IS, Roberts LR, Kang KJ: Genes associated with recurrence of hepatocellular carcinoma: Integrated analysis by gene expression and methylation profiling. J Korean Med Sci 2011, 26(11):1428-1438.

119. Wang Y, Cheng J, Xu C, Liu S, Jiang S, Xu Q, Chen X, Zhuang H, Lu F: Quantitative methylation analysis reveals gender and age differences in p16INK4a hypermethylation in hepatitis B virus-related hepatocellular carcinoma. Liver Int 2012, 32(3):420-428.

120. Saelee $P$, Chuensumran U, Wongkham S, Chariyalertsak S, Tiwawech D, Petmitr S: Hypermethylation of suppressor of cytokine signaling 1 in hepatocellular carcinoma patients. Asian Pac J Cancer Prev 2012. 13(7):3489-3493.

121. Chu HJ, Heo J, Seo SB, Kim GH, Kang DH, Song GA, Cho M, Yang US: Detection of aberrant p16INK4A methylation in sera of patients with liver cirrhosis and hepatocellular carcinoma. J Korean Med Sci 2004, 19(1):83-86.

122. Wang J, Qin Y, Li B, Sun Z, Yang B: Detection of aberrant promoter methylation of GSTP1 in the tumor and serum of Chinese human primary hepatocellular carcinoma patients. Clin Biochem 2006, 39(4):344-348

123. Tan SH, Ida H, Lau QC, Goh BC, Chieng WS, Loh M, Ito Y: Detection of promoter hypermethylation in serum samples of cancer patients by methylation-specific polymerase chain reaction for tumour suppressor genes including RUNX3. Oncol Rep 2007, 18(5):1225-1230.

124. Zhang YJ, Wu HC, Shen J, Ahsan H, Wei YT, Yang HI, Wang LY, Chen SY, Chen CJ, Santella RM: Predicting hepatocellular carcinoma by detection of aberrant promoter methylation in serum DNA. Clin Cancer Res 2007, 13(8):2378-2384

125. Chang H, Yi B, Li L, Zhang HY, Sun F, Dong SQ, Cao Y: Methylation of tumor associated genes in tissue and plasma samples from liver disease patients. Exp Mol Pathol 2008, 85(2):96-100.

126. Hu L, Chen G, Yu H, Qiu X: Clinicopathological significance of RASSF1A reduced expression and hypermethylation in hepatocellular carcinoma. Hepatol Int 2010, 4(1):423-432.

127. Iyer P, Zekri AR, Hung CW, Schiefelbein E, Ismail K, Hablas A, Seifeldin IA, Soliman AS: Concordance of DNA methylation pattern in plasma and tumor DNA of Egyptian hepatocellular carcinoma patients. Exp Mol Pathol 2010, 88(1):107-111.

doi:10.1186/2050-7771-2-5

Cite this article as: Mah and Lee: DNA methylation: potential biomarker in Hepatocellular Carcinoma. Biomarker Research 2014 2:5.

\section{Submit your next manuscript to BioMed Central and take full advantage of:}

- Convenient online submission

- Thorough peer review

- No space constraints or color figure charges

- Immediate publication on acceptance

- Inclusion in PubMed, CAS, Scopus and Google Scholar

- Research which is freely available for redistribution

Submit your manuscript at www.biomedcentral.com/submit
( Biomed Central 